paticut had the movements of St. Vitus' lunce, mul at other times slowed atluetosis in both arms and legs, amol nt still others merely the twitching of epilepsia contimn. The explanation of this vuriability in type of mator disorder probulaly is that the clanacter of the moveunents elepenels largely on the intensity of the irritation is werll os on the arcin covereal liy the lesion.

'The important thing in angmosing the condition is to fiul the mulerlying cunse. 'Tlie diagnosis of brain tumor in my cuse wns based entirely on the ocenrrence of the symptoms of n focal lornin lesion in a porson suflering from comreinomin. It is nlways safe to diaguose cerchoral metastasis in any ense of carcinoma in whiel corebral symptome oceur if lomorrlunge and thromosis can be excluned. 'The alssence of (dloked disk, (creloril vomitimg, vertigo,

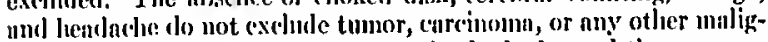
nimt growth lecing present elsewhere in the bod!y, and the presence of focal symptomis points strongly toward it becantse the classical symptoms of tumor occur ouly when the growth has nttnined some size, lut a very smull tumor nuy couse foenl symptoms if situated in uny part of the cortex having specialized functions.

\title{
PULSUS ALTERNANS.
}

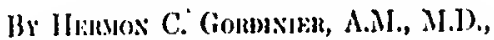

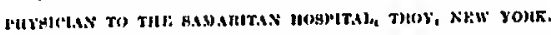

Is 1872 'J'rumle, in an alumiralole urticle, directed attention to n

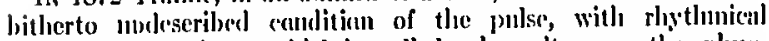
irrcgularity in volume, whiclo lac callecl pulsus alterunns, the splyygauogram showing wives of large and small annolitude, following cach other in regular suceression. Ile also noticed in the cuse which lie deseribed that while large and small bents were placed olterontely thronglout, the interval wlijeh sepirnted the large from the small beats exiecelerl that which separated the small from the large beits. Ile furtlier obscrved tluit the rlyytlum of the beort's u(ction was perfectly mormal.

Desprite (l)is early publication of 'I'ranbe no otloc case of a similar

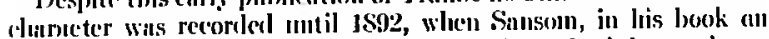
the Ileart and Aorla, refers to 11 case of cereloml licmorrliage, ('heyne-Stokes respiration, and rencral arteriosclerosis, with raliograms showimg typical pulsus ultermms. IIe stutes that the penliar Jernugement of the rlyothon of the pulse as seen in the splyygmogrim was not at any time detcetuble by the linger. It is at cxample of alteruating polse, I more nmjle one beiug always succeceled ly a less ample tracing, eneh beit being perfect in nll 
its elements, the irregnhnrity being in volume onls, and the eyclic secunence beiug invariable. Sausom silys, to expluin the inrge followed by the small pulse, we must assmue thut the ventricle delivers a full content in the large beat and $n$ imperfect content in the sumll hent. 'The nervous mechanism which regnlate's this ocenrrence is the vagus. 'Ille lesion alfecting its origin in the floor of the fourth ventricle is one which, calling into pluy its function of inhibiting the loeart's nnovements in slight degree, is insullicient to elongate the diastolic panse, lout antagonizes the ss'mpatletic incompletely', so that this indheone of the hitter comes into play. too soon in every altermite cycle. He also refers to muother cuse of clinieal alternation ocenrring with the onset of Cleyne-Stokes brenthing. IJering believes that both the experimental and elinical alteruntion is to be explained on the hypothesis of a lyposystole or partial asystole. Ile las observed in the exposind henrts of lower animals that nuder patleologieal conditions nll the henrt suscele fibers are not in the snme degree of contraction; thut dus "ut the smaller beat of alternans, different degrees of contrnction of the ventricle oeeurred. In this study Ilering also showed thit when tracings were takeu from the elinienl apex, or upex of the left vent ricle in animals, the larger wave of the (ardiogram corresponded to the sumller wave of the radiogram, thus produciug "distinet incongrnity between the nupex beat nnd the oulse curve. On the other liand, when the eardiogram was takeji from the third left intereostal space, or over the body of the right vent ricle, thie highest upstroke of the eardiogram eorresponder to the strong heat of the radial. 'These results were constant and repentedly observed. After the deatlı of the animals needles were inserted through the intereostal spaees at the points where the enrdiograns were taken, and oul opening the thoras it was found that the needle in the fifth intereostal space was lodged in the left ventricle just above tlic ajex. 'The needle in the third intercostal space was foumd in the comus of the right ventriele.

IJering believes that this incongruity between the cardiograms from the apex and those from the coms region, and the radiograph enrves in alternaus shows that the musenlature which eauses the apex beat has little or no propelling elfeet on the eontents of the left ventricle. Ile further states that al ternation is dne to a disturbance of contractility withont disturbanee of rhythm, mpidity of rate, or lack of stimulus prodnction, bnt is dependent on pat hologienl elianges in eertain arens of the myoeardinm, the smaller beat being au evidence of the fact that the diseased arens of the myocardium renet to stimulus prodnetion bnt slightly or not at all.

'l'hese observations of Ilering were verified and somewlint elaborated by Rihl, who in 1906 reported 4 enses of clinieal alternation, with two antopsies. Sll 4 eases were aecompanied by general arterioselerosis, eluronie inyocarditis, and lypertension. In the 
3 ereses that cance to motopsy murked myocurelial dhanges were fonol associnted with general arteriosederosis and ehromice incterstitial meplatis. In one aise the eoromenry arteries were grently scleresed

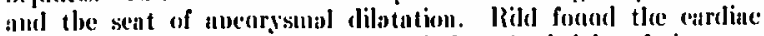
rhythm perfectly normal. Ile foumd that the lecight of the apes lifferel, a large atal small bent following encli otleer iu regular sacession. 'Tlois slows alternation in the left ventriele. None of his eases showed evidenere of alternation of the anricles. In oll his case's an ocensional extrisyistole was olsserved, after which io eacle instance the alternation wons more foromomued. Ile alsa

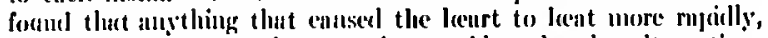
such us walking or otler exercise: womlal make the altermations more nurkerl.

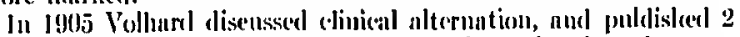

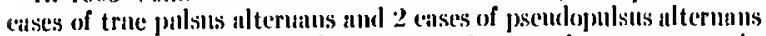
or continucens bigenuina. 'Tlos anses of true alterments were iu yonog men, onc il ense of mitral stenesis witle deconpensition, inged twenty-seven perars, and the otluer a ctise of chronic Briglet's

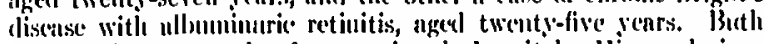

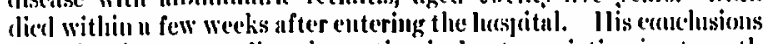
were that in man cardiace alteruntion is done to varintion iu strongth af the eomtraction of the anrieles as well as the ventricles; that the clange in the pulse is dee to dillerence in velume amel that the conrlinte rlythm is alesolutely normul; that the sianller witve of

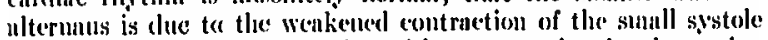
plis tlee high nortie pressitre; that with extrasystoles the ultoriatian

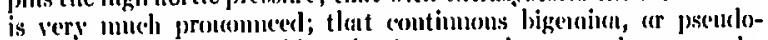
pulsiss altcrinans, resembles colosely true nltermans, lat may be

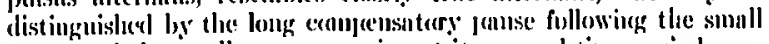
wave, ancl the small wave ocenrring it its normal time period.

Engleman las showa from experiouents on lower minimals that alternation is due to disturlances of contratility and not comeluetiv-

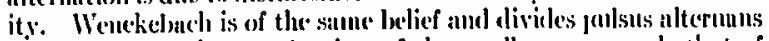
iinto two fornas: In (one the time of the small wrove exereds that of tle large, and the other in which the time interval of the small wave is tlec shorter. 'Jle first form lo exphaius loy tlec fact that the sucall waye is trinsmitterl more rapielly ince the norta than is the larger; and tlee seccolel form, with the large time interval of tlee small wave, by the hypothesis that ulternation is alue tu wealeneel or exlanusted coutrnetility.

Ilollman Jedieve's that, owing to tle distarlocel funcetion of coutractility existiug in alternation, contraction orecurs more guiclily tham lormiol, ancil hence the periods of time of the sy:stole anel cliastole

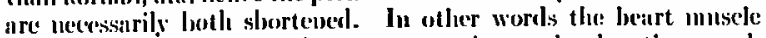
reaclacs the pecint of maximuna contraction and relaxation much more (juickly tlaum iu lealth.

Mackencie, in his book on Discuses of the Heurl, scrond enlition, 
states that a striking and characteristic: sign of exlansted contractility is sometimes secol in the size of the punse bent. He further states that "I huve repentedly alwalt mom the fact that the deviation and foree of contraction alepend in a measure on the length of the preceling porion of rest. In learts with good cont ran tility, recovery ufter a contraction is so rapiel that litte or no diflerenee (an be detected in the size of the bent nfter panses, of vurying duration. In cises of exlunusted contratility, on the other linul, recovery is slow, so thint the sime of the beat lass a distinet relatiou to the length of the precerling dinstolic punse. "This is exemplitied in ases of extrasystoles. In those with good coutractility the snceceding hent following the complensiting punse may not be much increased, or maty le: very large, and tlee sueceeding hents mny be almost miform in size. Whacreas the sime phenomenom ocenrring in hearts with exhalusted coutractility, the large leat following the diustolic punse, mily he followed hu several sumaller lents of vorying size in regular alternation. This aliflerenee in the size of the lucats is an important anc, as it indicutes a grase cxlumstion of contruetility: Nat infrequently the diflerence in the size of the bents persists for a sloorter ar longer period in such mumer that the large leat alternates with the small beilt, the pulsuls alterIuIIs.

Machemaic explaius the pulsus nltermans as follows: When contractility is depressed, if time he nllowed for a full and stronge

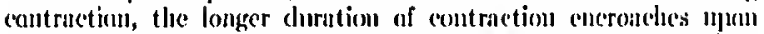
the perial of rest, so that by the time the next stimulus arrives the countructility lats not sulliciently recosered and a smaller and slunter contraction necurs, is this contriction is sluorter in duration the period of rest is therely lemgthened hefore the next stimmlus arrives, so that the coutraction would be strouger and larger; being larger it will again eneroach upou the period of rest and the process of altermation goes om.

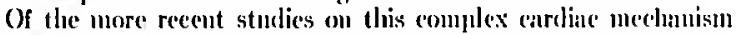

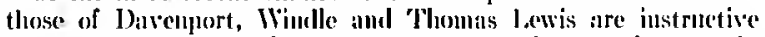
and interesting. Windle states that pulsus alteruans is properlygiven only to thint form of pulse in which a stromg beat is regularly followerl by a weaker one, the doration of the pulse pueriouls lecing gencrally egnal, although at times there muy be slighit altermation in the riptime of the heats us well ats in the force; but the diflerence in chration from one pulse to the next is small, and invarialoly the larger porial helonging to the stronger lacat, the wenker beat being therefore slightly delayed. From the polygraphie cirves token from bis twelve eases, Vindle states that la obsersed but one example of altermation of the climieal apex, while in all disparity in foree of altermite radial punlses was decided and at times ext reme.

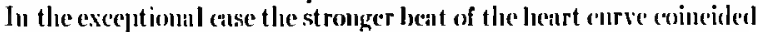
with the weaker one of the julse. 'Thus this exmulle ronfirms 
Ilering's observations. IIe also offers ju explauation of this appareutly ineougroous phenowenon, I lering's theory that the musenlature which forus the apex is not concerned in propelling the ventrieular contents into the aorta. In this latter ease alteruation was often) prouonneerl in records of the jugnlar pulsation; invarinbly the large $a$ wave eorrespouled to the higher of the radial pulse bent. Ile observed no variation in intensity of the piteli or duration of the leart sounds or murimurs eoincident with alternation of the pulse. IIis observations lend support to the view of Ilering that alteruation of the heurt beat una be che to 1 partinl systole of the ventricle. I.ewis states that heart alternation oecurs uncler two ciremustanees: (1) when the eardiae uncisele is not altered structurally, as an necompaniment of great rapiulity of rate; (2) when the pulse is of normal rate and muder such cireinustances the musele is markedly degencrated.

I ewis' experiueuts were upou rablits with ligature of the coronary urteries. Ilc found that obstruction of one or other eoronary artery was followed by rapiel and new rlyytluns arising in the ventricle, the ventricular rlyythm dominutiug that of the cardiae climubers, aud that if tle heart rute is greatly inerensed, ulteruation frequently appears both of the ventricles and anricles independently. is a result of these experiments, Iewis observed a divergence between the alternation iu the ventriele und earoticl, and expluins this phenouncuon on the coexistence of alteruation in the foree of the amrienlar contractions, thus supporting the view of Vollumerl, wloose tracings slowed thant the large apjical curve corresponded to the sunaller raclial beat alteruation ocenrring in the wuplitude of the a waves in the jugalar, the small radial beat being preeded by the small a wave.

Lewis furtlier states that the electrocarliographie curves obtuined in elinical alternation are similar to those obtuined experimentally, there being a divergence between the heighlits of $R$ aud $T$ waves aud the anplitude of the radial upstrokes. 'These facts (lemoustrate the ideutity of elinical and experimental ulteruatiou.

From a careful survey of the above-mentioned olservations one is led to the opinion that both clinienl and experimental alteruntious is the result of varying degrees of impairuent from exlumstion of thut Jnost iuportunt funetion of the myocardian, contractility, which may be due to temporary exhanstion from the overwork of great rupidity of netion or to permanent exhumstion und early cardiac fuilure, the result of grnve pathological changes in the unyo'arclium. "The sechueuce of events of eontraction of the curcliae climmber in altermution is normal. There is no defect of conductivity and the unyoeardiun responds to stimulus production. 'The only ubuoruml rlythun is the vuriation in volume of the pulse beits aud veutricilar output, ench lurge beat beiug suceeded by a swaller one, and so on indefinitely. 'This variation in amplitude 
of the pulse bent, which is nn evidence of exhansted contractility is of itself, owing to the lack of time interval between the small and large bent and the greater interval between the large nud sumall beit, a metnace to the further restoration of this function, beenuse of the marked shortening of the preceding diustolic pause, which is so essential to a full restoration of the function of contractility. It is this shortening of the diastolie panse in all enses of long-contintted taeliyeardin that results in early cardine exlunustion.

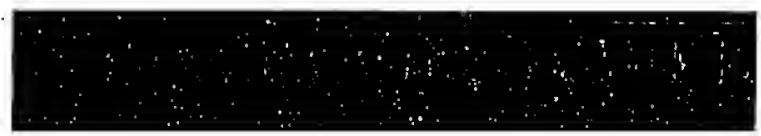

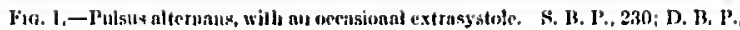

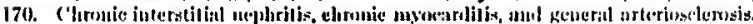

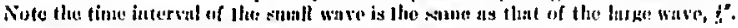

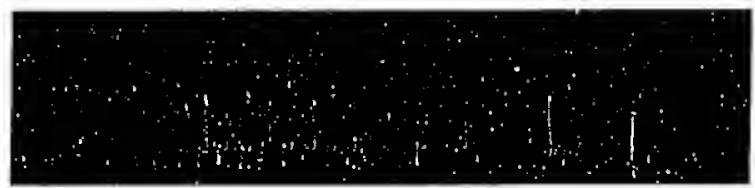

Fu. 2.- Itaruxy"unal taphyeardia which conthued six dhys, showing the alternation of acule myorarlial axlunustiois.

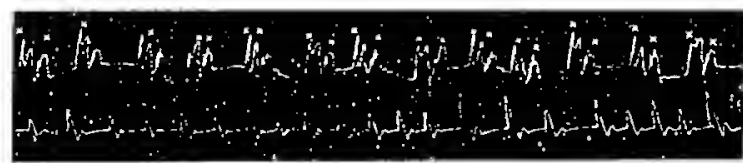

Ing. 3.-I'seudopulstus nlternans, or conimuons bigeming due lo extrasjostoles. Nliltal slenosis and regergit:utiou.

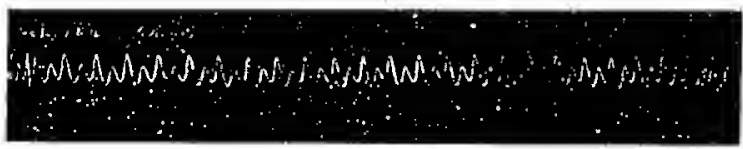

Fis. 4.-Dicrotism resendling elinical alleruation, second week of typhoil.

'T'emporary exhanstion of contractility often occurs with the production of a typical pulsus altermans from an overtaxution of the curdinc musculature, the result of a too rajpid rate, such as may occur in paroxysusul taclugenrelia, anrieular flutter, anuricular 


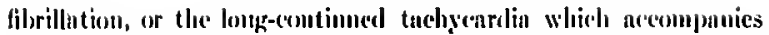
(irances' discitse. Experimentally it may be prodencel in lecilthy learts be clectrienal stimulation, the injertion into the bloodstrenin of dlipitalis, untiarin, uconitin, hlyoxylsinure, and hemol,tic sermun. It is most freculently encomintered, howerer, when the heart is benting within its uormal rate, and when it deuotes a grave pothologienel conclition of the mevocareliom, with firiling contractility. Mlost of the observed ense's of this trpe of pulsus alterians have ocenrred in patte'nts with general arterioscherosis nol hypertension,

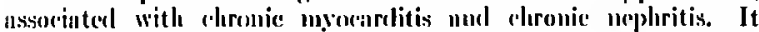

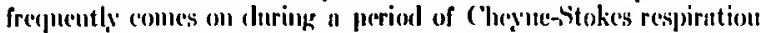
and contimes to the fatil issice. It is nistinlly not observed, however, mutil compecessation is failing ancl tbe henre chumbers are sull'rring from elilatation, the heart fibers having mulergone both fibroid indel fatty alanuges. It is uot at all omerommon in the grently dilated henrts of mitral steuosis or insuldieveney where decompentsit-

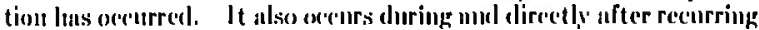

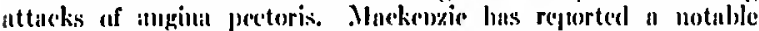
(eximple of this sort, and onc of the five ensi's of elinical alternation

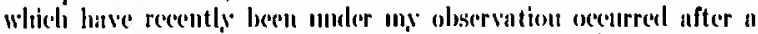
repectition of attacks of angiua peretoris, and listed but a weck,

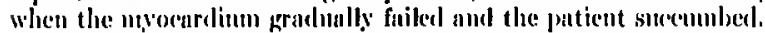

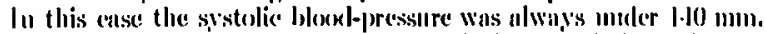
Ilg. Alternation freguently counes on douring n period of r'hey'nestokes respiration and then continues to the fatal issue.

I'le relation of extrassistoles to alteritation is most iuterestinf

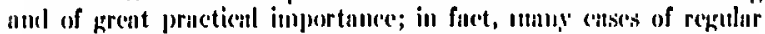
bigemina have been confused or mistnken for mul cleseriberl as

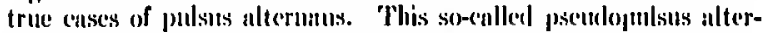

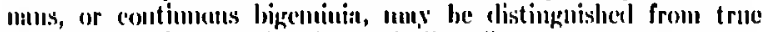
alternans ly' the lontr-time interval, diastolie or long comulensitory pallse following colch sonall or extrasystolie bent, and this in turu being followed lyy a larger beat, while the small beat hus its normal time interval; whereas in true pulsus alteruins the houger poriod follow's the large beat or the large and suball beat are cepuidistant from cicls other.

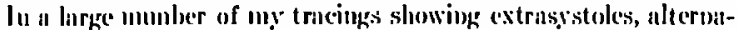
tion lans freepiently sucereceled for a single or a mimber of bents, the large wave following the long eompensatory pentse after the

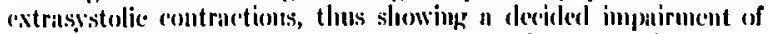

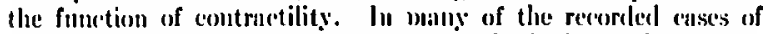
true ulteruntion an ocrusiontal extrusyistole is interpolaterl, and following snch extra beits the alternation immediately beromes more in evidence, Not only maty ultermution follow extruss'stoles, but, as slown by Windle, it of teil preeceles the extrastistolie contractions. Several siteli exumples la ve come muler my observation.

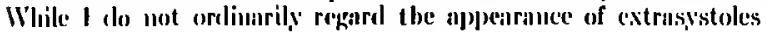
as of evil prognostic iniport, I do so regarel those extrisystoles 
which by repeated olsservation ure foumd to be imvariably followed by ulterintion extending over $n$ comsiderable perionl of time. In

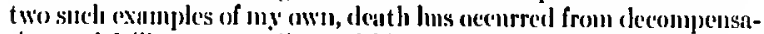
tion and fajling myocardimm within two years.

Of the 5 cases of clincal alternation which have been moler my care for the past two venrs, 3 have died-ome at the age of sey'entycight rears, of failing henrt, following a scries of at tacks of angina pectoris, resembling a true unginoid statns, with the elinicul evidences of general arteriosderosis and chronic neploritis, withont hypertension. One died smlelenly, when uged sixty-eight years, of genernl arteriosclerosis, ltiglı bloml-pressure, chronic nepliritis, and chronie myocarditis. A third, a man, aged forty years, died with all the evidence! of decompensution, Cheyne-sitokes brenthing, and uremia, the blood-pressinre remaining higl mntil ancar the end. 'The alteruntion in this case was first olsserved at the onset of the altered respiratory rlytho. The 2 ases now living are clinicully typoical cxumples of interstitial neploritis, general arteriosclerosis,

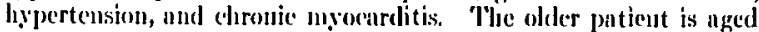
sevenity-two years and the otlee fifty-two years.

In I of these cases it was impossible to detect by pulpution of the rodial pulse the slightest evidenee of alternation aror could one perecive loy palpution of the clinical apex the slightest evidence of sucls a condition. la one eise, lowever, tlo variation in volune between the liarge and sinall beat was so grent that palpation of the radial was higlily suggestive, although not positive, of alternation.

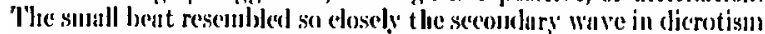
tlut I was nnad)le to distingnisli between it and alternation nuti] raliograns were taken. 1 therefore believe tlat palpation alone of any artery, radial or eiratid, is a poor index of the presence of alteriation or of the condition of the true action of the heart or of the leciglit of the blool-pressure. I ibobelieve, loweser, that defects of contractility from myocarelial degeneration in the permement irregnlarity of auricular filorillation, or eontiunous bigenina, mas" be detected by compuring the rate of the radial pulse with thit of the apex heat, determining the latter either by palpation or anserenlation, and noting the eleficit hetween the rate of tha apex and that of radiul. It is no Inemomom observation to find that a third or lailf of the systoles of the left ventricle fuil to lee registered at the wrist. Many of the sistelice antractions are so feeble that the intraventricular pressinre doess not overeome that of the anta, and therefore the nortic valve is not lifted. If, lowever, the aortic pressure is overeme the jumlse fails to reach the wrist becaltse of the high blook-pressure plus tle periphoral resistance.

In IIy cuses of alternation no change in the intensity, pital, or (punlity of the lenrt sommds were detectable. An extra or interpolated third somend was never hered. In one case, with a relatively

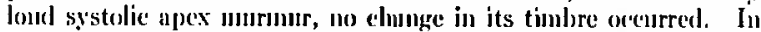
3 case's no marked alternation was observed in cardiograms tuken 
from the clinical apex. In 2 ease's, lowever, such alternation was very distinct. 'I'he respirutory excursions, becuntse of the dyspuncil in individuals with minocardial insuflieicncy, is so greit that it is ofteu diflicult without temporary ecssation of the respiratory act to get sitisfactury pircliograms. In all cases the rly'tlinn of the lieart's astion was normal. In three of the enses where satisfactory phlehograns were obtainel the a-c interval was not inereased, showing that conductivity was normal.

Fronu this study the folluning conclusions may be drawn:

1. 'That pulsus altermans, while not common, is not very rarc. I agree with Mankeenzis: and Windle in giving it the thiri place among pulse irregulatrities, extrasystoles being pluced first and the persistent irregularity of antricular filurillntion the second.

2. ('linicial alterustion is freegnently werlooked beconse it connot be recoguized without the graphlie registration of the pulse.

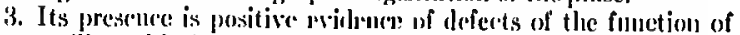
contractility, this in turn buing ilue to tomporary or permanent. myocardial chinges.

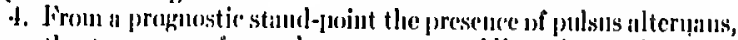
save the temporary lorm, due ta great rapidity of rate, is grave, Is it iudientes extensive myenrelial degeneration, most patients

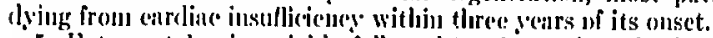

5. Extrasystoles, invarialuy fullowenl by alternation, also indicate exlalustion of contractility aud carry witl them a grave progunsis.

(i. I'ersistent false bralyiardia, ilue to ferble systoles, where the deficit between the apex lient and the pulse rate is but little ultered by the exhibition uf eardine tonies, such as digitalis or strophuntluss, also indicute grave sleffects of contractility, witlo crtensive myocardial deguncration and unfạvoralble proguosis.

\section{II:FHIT:ACI:S}

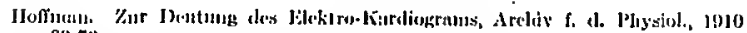
Ixxxy, 39-72,

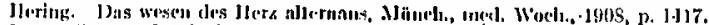

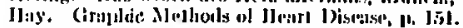

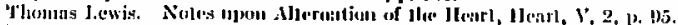

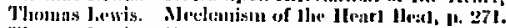

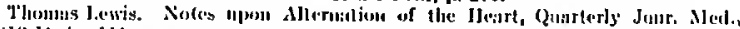
[9](l.] ]. iv. [.]l.

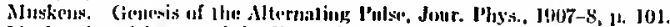

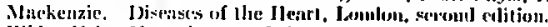

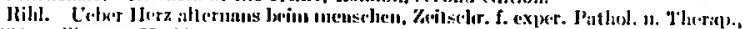

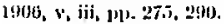

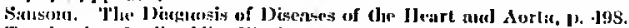

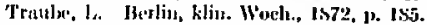

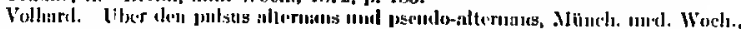
$1005,13.500$.

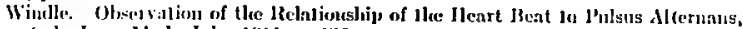

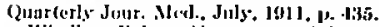

Winclle. Pulsus diferoinus aud ils llelalion to lixlm-sysloles, Quarlerly Jour. Med., Jaנumiry, 1911, p. 113.

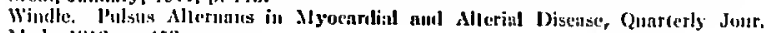
Med.. 1913, p. tisis. 